\title{
ANALISIS USAHA INDUSTRI TAHU SKALA RUMAH TANGGA DI KECAMATAN KARTASURA KABUPATEN SUKOHARJO
}

\author{
Fauziyah Rafi' Nur Utami ${ }^{1}$, Minar Ferichani ${ }^{2}$, Umi Barokah ${ }^{3}$ \\ ${ }^{1}$ Program Studi Agribisnis Fakultas Pertanian Universitas Sebelas Maret \\ ${ }^{2}$ Program Studi Agribisnis Fakultas Pertanian Universitas Sebelas Maret \\ ${ }^{3}$ Program Studi Agribisnis Fakultas Pertanian Universitas Sebelas Maret \\ Email korespondensi : fauziyahrafi@gmail.com
}

\begin{abstract}
. This study purpose to find out the cost, revenue, profit, profitability, business efficiency, business risk and sensitivity in tofu business in the centre of the tofu industry in the District of Kartasura, Sukoharjo Regency. The basic method used in this research was descriptive. The determination of the sample area was purposive. The determination of respondents was done by simple random sampling method. Data analyses used in this study were cost analysis, revenue, profit, profitability, business efficiency, business risk, and sensitivity analysis. The results of this study indicated that the average total cost of tofu industry Desember 2018 was Rp 58.050.003,00 with the average revenue of $\mathrm{Rp} 65.430 .850,00$ so that the average profit obtained was Rp 7.380.847,00 and profitability of $13 \%$. The tofu business being run is already efficient with an $\mathrm{R} / \mathrm{C}$ ratio of 1.13. The value of the variation coefficient is 0.64 and the lower limit value of profit is $-\mathrm{Rp} 2.057,792$. This means that tofu businesses in Kartasura Subdistrict are at risk. Tofu businesses was more sensitive to changes in the parameters of decreasing sales value than increases in material and labour costs.
\end{abstract}

Keywords : Business risk, efficiency, profit, sensitivity, tofu.

\section{INTISARI}

Penelitian ini bertujuan mengetahui biaya, penerimaan, keuntungan, profitabilitas, efisiensi usaha, risiko usaha dan analisis sensitivitas pada usaha industri tahu skala rumah tangga di sentra industri tahu Kecamatan Kartasura Kabupaten Sukoharjo. Metode dasar penelitian yaitu deskriptif. Penentuan daerah sampel secara sengaja (purposive). Penentuan responden dilakukan dengan metode simple random sampling. Analisis data yang digunakan yaitu analisis biaya, penerimaan, keuntungan, profitabilitas, efisiensi usaha, risiko usaha, serta sensitivitas. Hasil penelitian ini menunjukkan rata-rata biaya total yang dikeluarkan oleh industri tahu skala rumah tangga bulan Desember 2018 sebesar $\mathrm{Rp} \mathrm{58.050.003,00} \mathrm{dengan} \mathrm{rata-rata} \mathrm{penerimaan} \mathrm{sebesar}$ Rp 65.430.850,00 sehingga keuntungan rata-rata yang diperoleh sebesar $\mathrm{Rp} 7.380 .847,00$ dan profitabilitas sebesar $13 \%$. Usaha yang dijalankan sudah efisien dengan $R / C$ ratio sebesar 1,13 . Besar nilai koefisien variasi 0,64 dan nilai batas bawah keuntungan sebesar $-\mathrm{Rp} 2.057 .792,0$ berarti usaha tahu berisiko. Usaha tahu yang dijalankan lebih sensitif terhadap perubahan parameter penurunan nilai penjualan daripada kenaikan biaya bahan baku dan tenaga kerja.

Kata Kunci : Efisiensi, keuntungan, risiko usaha, sensitivitas, tahu.

\section{PENDAHULUAN}

Tahu merupakan gumpalan protein kedelai yang diperoleh dari hasil penyarian kedelai yang telah digiling dengan penambahan air (Sarwono dan Saragih, 2016).Tahu dikenal sebagai makanan rakyat karena harganya yang murah, mudah dijangkau oleh seluruh kalangan masyarakat. Pada umumnya tahu dijadikan sebagai lauk pauk untuk menggantikan daging (protein hewani) karena harganya yang lebih murah bila dibandingkan dengan daging. Selain harganya murah, tahu diminati karena makanan sehat dan dapat diolah menjadi berbagai macam masakan. Banyaknya masyarakat yang mengkonsumsi tahu mendorong bermunculnya industri penghasil tahu, salah satunya terdapat di Kabupaten Sukoharjo yang 
ISSN : 2621-3974 (online)

Volume : 02 Number: 02 (2019)

ISSN : 2622-6154 (print)

memiliki banyak produsen tahu. Industri tahu di Sukoharjo merupakan jenis industri makanan yang memiliki nilai produksi tertinggi daripada industri makanan lainnya.

Tabel 1. Daftar Sentra Industri Makanan di Kabupaten Sukoharjo Tahun 2016

\begin{tabular}{llrrr}
\hline \hline No & \multicolumn{1}{c}{ Nama Sentra } & $\begin{array}{r}\text { Unit Usaha } \\
\text { (Unit) }\end{array}$ & $\begin{array}{r}\text { Jumlah Tenaga } \\
\text { Kerja (orang) }\end{array}$ & $\begin{array}{c}\text { Nilai Produksi } \\
\text { (Rp) }\end{array}$ \\
\hline $\mathbf{1 .}$ & Tahu & $\mathbf{3 1 2}$ & $\mathbf{8 6 2}$ & $\mathbf{4 1 . 3 3 7 . 9 4 0}$ \\
2. & Tempe & 501 & 1.396 & 24.752 .500 \\
3. & Emping Mlinjo & 570 & 1.235 & 14.470 .000 \\
4. & Kerupuk & 194 & 521 & 10.460 .000 \\
5. & Jenang dan Krasikan & 61 & 219 & 9.975 .000 \\
6. & Pengolahan Kacang Tanah & 60 & 240 & 6.142 .500 \\
7. & Jamu Tradisional & 67 & 330 & 3.634 .000 \\
8. & Tape & 88 & 167 & 1.836 .000 \\
9. & Marning Jagung Industri Kecil & 10 & 45 & 1.102 .500 \\
10. & Rengginang & 16 & 40 & 141.750 \\
\hline \hline
\end{tabular}

Sumber: Dinas Perindustrian dan Tenaga Kerja Kabupaten Sukoharjo

Berdasarkan tabel 1 diketahui bahwa nilai produksi industri tahu mencapai Rp 41.337.940,00 yang merupakan nilai produksi industri makanan tertinggi di Sukoharjo pada tahun 2016. Hal ini menunjukkan bahwa usaha tahu di Sukoharjo merupakan usaha yang produktif dan prospektif. Banyaknya konsumen tahu menjadi salah satu penyebab usaha tahu memiliki nilai produksi yang tinggi.

Di Sukoharjo terdapat 312 unit usaha industri tahu dengan total jumlah tenaga kerja sebanyak 862 orang. Industri tahu yang ada masih berskala rumah tangga dan kecil. Berdasarkan data Dinas Perindustrian dan Tenaga Kerja Kabupaten Sukoharjo diketahui bahwa sentra industri tahu yang terdapat di Sukoharjo tersebar pada beberapa kecamatan. Tabel 2. Daftar Sentra Industri Mikro dan Kecil Tahu di Kabupaten Sukoharjo Tahun 2016

\begin{tabular}{lcc}
\hline \hline \multicolumn{1}{c}{ Kecamatan } & Jumlah Unit Usaha & Nilai Produksi \\
\hline Nguter & 76 & 9.447 .750 \\
Kartasura & $\mathbf{5 4}$ & $\mathbf{9 . 0 7 7 . 2 5 0}$ \\
Grogol & 67 & 8.895 .250 \\
Weru & 54 & 6.218 .940 \\
Bulu & 24 & 3.025 .750 \\
Baki & 22 & 2.873 .000 \\
Gatak & 15 & 1.800 .000 \\
\hline \hline
\end{tabular}

Sumber: Dinas Perindustrian dan Tenaga Kerja Kabupaten Sukoharjo

Berdasarkan tabel 2 diketahui bahwa sentra industri tahu terdapat di 7 kecamatan yaitu Kecamatan Nguter, Kartasura, Grogol, Weru, Bulu, Baki, dan Gatak. Kecamatan Kartasura memiliki nilai produksi tertinggi kedua dengan jumlah unit usaha industri tahu sebanyak 54 unit. Nilai produksi di Kecamatan Kartasura sebesar Rp 9.077.250,00. Nilai produksi di Kartasura lebih tinggi jika dibandingkan dengan Kecamatan Weru yang juga memiliki jumlah usaha industri sebanyak 54 unit. Hal tersebut mengindikasikan bahwa usaha industri tahu di Kecamatan Kartasura merupakan usaha yang prospektif.

Industri tahu di Kecamatan Kartasura melakukan produksi setiap hari, dimana terdapat 2 sentra industri tahu yaitu di Kelurahan Kartasura dan Kelurahan Wirogunan. Jenis tahu yang diproduksi di Kecamatan bervariasi yaitu tahu putih, tahu pong, dan tahu magel, akan tetapi sebagian besar industri tahu memproduksi tahu putih. Sebagian besar konsumen tahu dari industri tahu di Kecamatan Kartasura yaitu pedagang perantara yang berasal dari 
ISSN : 2622-6154 (print)

Surakarta, Boyolali, dan Klaten karena letak Kartasura yang berdekatan dengan daerahdaerah tersebut.

Usaha industri kecil tahu merupakan gambaran umum mengenai suatu usaha, dalam hal ini adalah usaha tahu dapat diketahui pemodalan usaha, ketersediaan bahan baku, sistem produksi, proses produksi, jenis produksi, biaya produksi, saluran pemasaran, dan pendapatan dalam proses keberlangsungan usaha. Produsen memproduksi tahu secara turun menurun sehingga proses produksi masih menggunakan peralatan yang masih sederhana. Usaha tahu di Kecamatan Kartasura banyak menggunakan kedelai impor dari pada kedelai lokal. Produksi kedelai di Indonesia yang semakin menurun jumlahnya dari tahun ke tahun disebabkan antara lain yaitu (Sudaryanto \& Swastika 2016): (1) produktivitas yang masih rendah, sehingga kurang menguntungkan dibandingkan komoditas pesaing lainnya, (2) belum berkembangnya industri perbenihan, (3) keterampilan petani yang masih rendah, (4) adanya gangguan dari organisme pengganggu tanaman (OPT), (5) belum berkembangnya pola kemitraan, karena sektor swasta belum tertarik untuk melakukan agribisnis kedelai dan (5) kebijakan perdagangan bebas (bebas tarif impor), sehingga harga kedelai impor lebih murah dari kedelai produksi dalam negeri. PemerintahHal tersebut mengakibatkan ketergantungan terhadap kedelai impor sehingga akan mempersulit usaha tahu karena harga kedelai impor yang berfluktuatif mengikuti nilai Rupiah yang ada. Oleh karena itu, penelitian ini dilakukan untuk menganalisis usaha tahu yang telah dijalankan oleh industri tahu yang ada di sentra industri tahu Kecamatan Kartasura Kabupaten Sukoharjo.

\section{METODE PENELITIAN}

Metode dasar yang digunakan dalam penelitian ini adalah metode deskriptif. Penentuan daerah penelitian dilakukan dengan metode purposive yaitu Kecamatan Kartasura Kabupaten Sukoharjo. Jumlah responden yang diambil dalam penelitian ini sebanyak 30 responden. Penetapan jumlah responden setiap desa dilakukan secara proporsional. Penentuan responden industri karak skala rumah tangga pada masing-masing kelurahan dilakukan dengan mengunakan metode simple random sampling. Penelitian ini menggunakan data primer. Teknik pengumpulan data dilakukan dengan wawancara, observasi, dan pencatatan. Penelitian dilakukan pada bulan Desember 2018.

\section{Metode Analisis Data}

\section{Analisis Biaya, Penerimaan, Keuntungan, dan Profitabilitas.}

Biaya produksi merupakan biaya yang dikeluarkan dalam proses produksi sampai menjadi output yang didalamnya termasuk barang yang dibeli dan jasa yang telah dibayar (Kadarsan, 1992). Perhitungan biaya produksi digunakan rumus sebagai berikut:

$\mathrm{TC}=\mathrm{TFC}+\mathrm{TVC}$

Keterangan : TC adalah biaya total industri (Rupiah), TFC adalah total biaya tetap (Rupiah), TVC adalah total biaya variabel (Rupiah).

Menurut Boediono (1999) rumus Total Revenue (TR) adalah penerimaan total produsen dari hasil penjualan outputnya. TR dihitung sebagai perkalian kuantitas output yang dihasilkan $(\mathrm{Q})$ dan harga jual output $(\mathrm{P})$. Perhitungan penerimaan total digunakan rumus sebagai berikut :

$\mathrm{TR}=\mathrm{Q} \times \mathrm{P}$. 
ISSN : 2622-6154 (print)

Keterangan : TR adalah penerimaan total industri (Rupiah), $\mathbf{Q}$ adalah jumlah output yang dihasilkan (Biji), P adalah harga jual output (Rupiah).

Keuntungan adalah selisih antara total penerimaan dan total biaya (Sunaryo, 2001). Keuntungan dapat dihitung dengan menggunakan rumus sebagai berikut :

$\pi=\mathrm{TR}-\mathrm{TC}$

Keterangan : $\boldsymbol{\pi}$ adalah keuntungan industri (Rupiah), TR adalah penerimaan total industri tahu (Rupiah), TC adalah biaya total industri tahu (Rupiah).

Tingkat profitabilitas merupakan perbandingan antara keuntungan dengan biaya total yang dinyatakan dalam presentase, dihitung dengan rumus sebagai berikut:

Profitabilitas $=\pi-\mathrm{TC}$

Keterangan : $\boldsymbol{\pi}$ adalah keuntungan industri tahu (Rupiah), TC adalah biaya total industri tahu (Rupiah).

\section{Efisiensi Usaha}

Menurut Rahadi (1999) menyatakan bahwaperhitungan efisiensi usaha yang sering digunakan adalah Revenue Cost Ratio (R/C Ratio). $R / C$ ratio menunjukkan pendapatan kotor (penerimaan) yang diterima untuk setiap rupiah yang dikeluarkan untuk memproduksi sekaligus menunjukkan kondisi suatu usaha, dapat dihitung dengan rumus sebagai berikut:

$\mathrm{R} / \mathrm{C}$ ratio $=\mathrm{TR} / \mathrm{RC}$

Keterangan :TR adalah penerimaan total industri tahu (Rupiah), TC adalah biaya total industri tahu (Rupiah).

\section{Analisis Risiko}

Pengetahuan tentang hubungan antara risiko dan keuntungan seyogianya menjadi bagian yang paling penting dalam pengelolaan suatu usaha. Hubungan ini biasaya diukur dengan koefisien variasi (CV) dan batas bawah keuntungan (L) (Hernanto, 1991). CV dihitung dengan menggunakan rumus sebagai berikut:

$\mathrm{CV}=\mathrm{V} / \mathrm{E}$

Keterangan : CV adalah koefisien variasi industri, $\mathbf{V}$ adalah simpangan baku industri (Rupiah), E adalah keuntungan rata-rata industri (Rupiah).

Mencari keuntungan rata-rata dengan menggunakan rumus sebagai berikut:

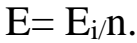

Keterangan : E adalah adalah keuntungan rata-rata industri (Rupiah), Ei adalah keuntungan industri pada responden i (Rupiah), $\mathbf{n}$ adalah jumlah responden (Orang).

Simpangan baku dapat dihitung menggunakan rumus :

$\frac{\mathrm{go}_{0}(E i-E)^{2}}{n-1)}$

Keterangan :V adalah simpangan baku keuntungan industri, $\mathbf{n}$ adalah jumlah responden (Orang), E adalah keuntungan rata-rata industri (Rupiah), Ei adalah keuntungan industri pada responden i (Rupiah).

Menghitung batas bawah keuntungan industri karak skala rumah tangga dengan rumus sebagai berikut :

$\mathrm{L}=\mathrm{E}-2 \mathrm{~V}$

Keterangan :L adalah batas bawah keuntungan industri (Rupiah), E adalah rata-rata keuntungan industri (Rupiah), $\mathbf{V}$ adalah simpangan baku industri (Rupiah).

Apabila nilai $\mathrm{CV} \leq 0,5$ atau $\mathrm{L} \geq 0$ berarti industri akan terhindar dari kerugian. Nilai $\mathrm{CV}>0,5$ atau nilai $\mathrm{L}<0$ berarti ada peluang kerugian pada industri. 


\section{Analisis Sensitivitas}

Analisis sensitivitas dilakukan dengan menggunakan tabel excel. Teknik analisis sensitivitas:

a. Melakukan identifikasi faktor-faktor perubahan parameter produksi yang mungkin atau dapat saja terjadi pada usaha tahu.

b. Perubahan tersebut akan berpengaruh terhadap keuntungan yang diperoleh produsen tahu.

\section{HASIL DAN PEMBAHASAN}

\section{Keadaan Umum Lokasi Penelitian}

Kecamatan Kartasura merupakan salah satu kecamatan yang ada di Kabupaten Sukoharjo Provinsi Jawa Tengah. Secara astronomis, Kecamatan Kartasura terletak pada

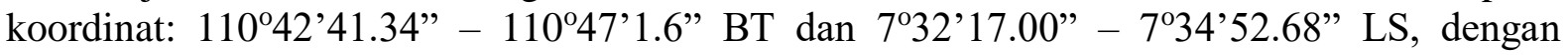
tinggi 91 - $144 \mathrm{~m}$ diatas permukaan laut. Luas wilayah Kecamatan Kartasura pada tahun 2017 yaitu 1.923 Ha atau sekitar 4,12\% dari luas Kabupaten Sukoharjo (46.666 Ha). Batasbatas wilayah Kecamatan Kartasura yaitu sebelah utara berbatasan dengan Kabupaten Karanganyar, sebelah timur dengan Kota Surakarta, sebelah selatan dengan Kecamatan Gatak, dan sebelah barat dengan Kabupaten Klaten.Kecamatan Kartasura terdiri dari 2 Kelurahan dan 10 Desa.

\section{Identitas Responden dan Karakteristik Usaha Industri Tahu Skala Rumah Tangga}

Responden industri karak skala rumah tangga rata-rata berumur 45 tahun. Sebagian besar responden industri tahu skala rumah tangga di Kabupaten Sukoharjo telah mengenyam pendidikan formal, walaupun tingkatan pendidikan responden berbeda. Rata-rata lama pendidikan responden tahu di Kabupaten Sukoharjo adalah 11tahun. Rata-rata jumlah anggota keluarga responden adalah 4 orang. Banyaknya jumlah anggota keluarga berpengaruh terhadap ketersediaan tenaga kerja keluarga, anggota keluarga aktif dalam kegiatan industri tahu. Rata-rata jumlah anggota keluarga yang aktif dalam industri usaha sebanyak 2 orang. Biasanya anggota keluarga yang aktif dalam kegiatan industri tahu adalah suami dan istri, sedangkan anggota keluarga yang lainnya bekerja di sektor lain, masih menyelesaikan pendidikan, termasuk usia belum produktif atau usia tidak produktif. Kisaran tenaga kerja luar keluarga di industri tahu sebanyak 2-3 orang.

Rata-rata responden telah mengusahakan tahu selama 19 tahun. Semakin lama mengusahakan, maka semakin banyak pengalaman yang dimiliki dan berguna untuk mengatasi kendala usaha yang dihadapi. Status usaha industri tahu skala rumah tangga di Kabupaten Sukoharjo sebagai pekerjaan utama, dimana responden melakukan produksi setiap hari. Sebagian besar responden mengusahakan tahu dengan alasan usaha warisan dari orang tua. Jadi responden mengusahakan tahu karena usaha tahu merupakan usaha turun temurun di keluarganya. Produsen industri tahu skala rumah tangga di Kabupaten Sukoharjo untuk menjalankan usahanya memerlukan modal. Seluruh responden menggunakan modal sendiri.

\section{Usaha Industri Tahu Skala Rumah Tangga di Kecamatan Kartasura}

Kecamatan Kartasura memiliki 2 sentra industri tahu yaitu di Kelurahan Kartasura dan Desa Wirogunan. Industri tahu yang ada di Kecamatan Kartasura memproduksi 3 jenis tahu yaitu tahu putih, tahu pong, dan tahu magel. Tahu pong dan tahu magel merupakan jenis tahu goreng yang memiliki perbedaan pada proses penggorengannya. Tahu pong dihasilkan dari 2 kali proses penggorengan, sedangkan tahu magel dihasilkan dari 1 kali penggorengan. Sebagian besar responden memproduksi tahu putih yaitu $96,67 \%$ responden, yang memproduksi tahu pong sebanyak 30\% responden dan hanya $10 \%$ responden yang 
ISSN : 2621-3974 (online)

Volume : 02 Number : 02 (2019)

ISSN : 2622-6154 (print)

memproduksi tahu magel. Hal ini disebabkan tahu memiliki ketahanan yang paling lama yaitu 4 hari, sedangkan tahu pong selama 3 hari dan tahu magel memiliki ketahanan paling pendek yaitu 2 hari. Rata-rata produksi tahu pada industri tahu di Kecamatan Kartasura bulan Desember 2018 sebanyak 889 proses produksi

\section{Analisis Usaha Industri Skala Rumah Tangga}

Besarnya keuntungan yang diterima industri tahu dipengaruhi oleh besarnya penerimaan dan biaya total. Penerimaan industri tahu merupakan nilai poduksi yang diperoleh dari perkalian jumlah produk dengan harga jual produk. Sedangkan biaya industri tahu meliputi biaya tetap (bunga modal sendiri, penyusutan, sewa tempat, biaya managemen) dan biaya variabel (bahan baku, bahan penolong, bahan bakar, tenaga kerja, pengemasan, listrik, dan transportasi).

Tabel 3. Rata-rata Biaya, Penerimaan, Keuntungan, Profitabilitas dan Risiko Usaha Karak Skala Rumah Tangga di Kabupaten Sukoharjo

\begin{tabular}{|c|c|c|}
\hline No & Uraian & Jumlah \\
\hline \multirow[t]{17}{*}{1.} & Biaya & \\
\hline & a. Biaya Tetap & \\
\hline & 1) Bunga Modal Sendiri (Rp/Bln) & 1.241 .183 \\
\hline & 2) Penyusutan Alat (Rp/Bln) & 1.277 .928 \\
\hline & 3) Sewa Tempat (Rp/Bln) & 1.313 .000 \\
\hline & 4) Biaya Managemen (Rp/Bln) & 1.518 .000 \\
\hline & Jumlah Biaya Tetap & 2.350 .112 \\
\hline & b. Biaya Variabel & \\
\hline & 1) Bahan Baku (Rp/Bln) & 37.499 .242 \\
\hline & 2) Bahan Penolong (Rp/Bln) & 1.823 .333 \\
\hline & 3) Bahan Bakar (Rp/Bln) & 3.969 .600 \\
\hline & 4) Tenaga Kerja (Rp/Bln) & 10.416 .950 \\
\hline & 5) Listrik (Rp/Bln) & 765.833 \\
\hline & 6) Transportasi (Rp/Bln) & 757.000 \\
\hline & 7) Pengemasan (Rp/Bln) & 467.933 \\
\hline & Jumlah Biaya Variabel & 55.699 .892 \\
\hline & c. Biaya Total & 58.050 .003 \\
\hline 2. & Penerimaan & 65.430 .850 \\
\hline 3. & Keuntungan (Rp/Bln) & 7.380 .847 \\
\hline 4. & Proftabilitas (\%) & 13 \\
\hline 5. & Efisiensi Usaha & 1,13 \\
\hline 6. & Risiko Usaha & \\
\hline & a. Simpangan Baku (Rp) & 4.719 .319 \\
\hline & b. Koefisien Variasi & 0,64 \\
\hline & c. Batas Bawah Keuntungan (Rp) & -2.057 .792 \\
\hline
\end{tabular}

\section{Sumber : Analisis Data Primer, 2018}

Tabel 3 menunjukkan bahwa rata-rata biaya total yang dikeluarkan industri tahu skala rumah tangga di Kecamatan Kartasura pada bulan Desember 2018 yaitu sebesar Rp 58.050.003,00 per bulan. Alokasi rata-rata biaya tetap sebesar Rp 2.350.112,00 per bulan meliputi biaya bunga modal Rp 1.241.183,00 per bulan, penyusutan alat Rp 1.277.928,00 per bulan, biaya sewa tempat sebesar Rp 1.313.000,00 dan biaya manajemen sebesar Rp 1.518.000,00. Perhitungan bunga modal menggunakan nilai suku bunga dasar Bank BRI yaitu 1,45\%. Menurut Downey dan Erickson (1987), biaya manajemen merupakan biaya yang memperhitungkan waktu dan kemampuan produsen dalam manajemen, besar biaya 
ISSN : 2622-6154 (print)

manajemen diibaratkan dengan kemampuan produsen mambayar orang lain untuk bekerja mengelola usaha tersebut.

Rata-rata biaya variabel industri tahu skala rumah tangga di Kecamatan Kartasura Kabupaten Sukoharjo pada bulan Desember 2018 sebesar Rp 55.699.892,00/bulan. Besarnya biaya variabel dipengaruhi oleh banyaknya produk yang dihasilkan. Pada bulan Desember, produksi tahu stabil seperti pada bulan lainnya. Akan tetapi, ada beberapa responden yang mengurangi produksi dengan alasan libur sekolah.

Rata-rata biaya variabel terbesar adalah biaya bahan baku yaitu sebesar Rp 37.499.242,00/bulan atau 67,33\%. Biaya bahan baku merupakan biaya yang dikeluarkan untuk membeli kedelai. Biaya bahan baku menjadi biaya variabel terbesar yang dikeluarkan responden dibandingkan dengan biaya variabel lainnya dikarenakan kedelai merupakan bahan utama dalam pembuatan tahu sehingga tanpa ada kedelai maka responden tidak dapat memproduksi tahu. Biaya bahan baku yang dikeluarkan tiap responden berbeda dikarenakan perbedaan jumlah kedelai yang digunakan per proses produksi dan harga beli kedelai. Kedelai yang digunakan adalah kedelai impor dari Amerika dikarenakan tahu putih yang dihasilkan memiliki warna lebih putih dan kenyal dibandingkan dengan kedelai lokal. Selain itu, tahu goreng yang dihasilkan dari kedelai lokal memiliki warna semu welu (kuning pucat), sedangkan tahu goreng yang dihasilkan dari kedelai impor memiliki warna kuning. Akan tetapi menurut Yulifianti dan Ginting (2012) tahu goreng yang dihasilkan dari kedelai varietas unggul Gema (Genjah Malang) memiliki warna, aroma, dan rasa yang hampir sama dengan tahu yang dihasilkan dari kedelai impor. Menurut Rohmah dan Saputro (2016) menyatakan bahwa kebutuhan akan kedelai terus meningkat dari tahun ke tahun linear dengan peningkatan jumlah penduduk, sementara produksi yang dicapai belum mampu mengimbangi kebutuhan tersebut.

Rata-rata harga kedelai pada bulan Desember 2018 di daerah penelitian sebesar Rp 7.207,00/kg. Rata-rata jumlah kedelai yang digunakan selama bulan Desember 2018 sebesar $5.213 \mathrm{~kg}$. Jumlah kedelai yang digunakan per proses produksi berbeda-beda untuk tahu putih, tahu pong, dan tahu magel. Rata-rata jumlah kedelai per proses produksi yang digunakan untuk memproduksi tahu putih sama dengan tahu magel yaitu $6 \mathrm{~kg} / \mathrm{masak}$, sedangkan rata-rata jumlah kedelai per proses produksi yang digunakan untuk memproduksi tahu pong yaitu $5 \mathrm{~kg} /$ proses produksi.

Rata-rata biaya variabel terbesar kedua adalah biaya tenaga kerja sebesar Rp 10.416.950,00/bulan atau 18,70\%. Tenaga kerja terdiri dari tenaga kerja dalam dan tenaga kerja luar yang meliputi tenaga kerja laki-laki dan perempuan. Besaran upah perhari tergantung pada banyaknya masakan atau produksi tahu perhari. Semakin banyak masakan maka akan semakin tinggi pula upah yang didapatkan oleh tenaga kerja. Rata-rata upah tenaga kerja laki-laki yaitu sebesar Rp 3.085,00/masakan. Rata-rata upah tenaga kerja perempuan yaitu sebesar Rp 2.118,00/sekali masak. Tenaga kerja laki-laki berperan dalam keseluruhan proses produksi meliputi perendaman, pencucian, perebusan, penyaringan, pembumbuan, pencetakan tahu, pemotongan tahu, hingga penggorengan. Tenaga kerja perempuan berperan dalam proses pemotongan tahu dan penggorengan.

Rata-rata biaya variabel terbesar ketiga adalah biaya bahan bakar sebesar Rp 3.969.600,00/bulan atau 7,13\%. Bahan bakar yang digunakan kayu awul, kayu bakar, rambut pari, dan limbah kain. Bahan bakar utama yang digunakan adalah kayu awul, seluruh responden menggunakan kayu awul sebagai bahan bakar produksi tahu. Rata-rata jumlah kayu awul yang digunakan dalam sebulan yaitu 500 sak. Satu sak kayu awul dapat digunakan untuk 2 kali masakan. Rata-rata harga satu sak kayu awul yaitu Rp 7.233,00/sak. Bahan bakar lainnya yang digunakan adalah kayu bakar, rambut pari, dan limbah kain. 
ISSN : 2622-6154 (print)

Rata-rata biaya variabel terbesar ketiga adalah biaya bahan penolong sebesar Rp 1.823.333,00/bulan atau 3,27\%. Biaya bahan penolong meliputi biaya untuk pembelian minyak goreng, bawang putih, garam, dan penyedap rasa. Bahan penolong hanya digunakan oleh responden yang memproduksi tahu pong dan tahu magel. Responden yang memproduksi tahu pong dan magel ada 10 responden atau 33,33\% dari total responden.

Rata-rata biaya variabel terbesar keempat adalah biaya listrik sebesar Rp 765.833,00/bulan atau 1,37\%. Biaya listrik digunakan untuk penerangan saat dibutuhkan, air sumur, dan menggiling kedelai karena mesin penggiling kedelai menggunakan sumber energi listrik. Biaya listrik per responden setiap bulannya antara Rp 520.000,00 hingga Rp 900.000,00. Perbedaan biaya listrik yang dikeluarkan setiap responden dikarenakan perbedaan penggunaan listrik untuk penerangan dan kebutuhan air untuk memproduksi tahu sertanya banyaknya produksi tahu setiap responden.

Rata-rata biaya variabel terbesar kelima adalah biaya transportasi sebesar Rp 757.000,00/bulan atau 1,36\%. Biaya tranportasi dikeluarkan untuk pembelian bahan dan menjual output yang dihasilkan. Sebanyak $66,67 \%$ responden mengeluarkan biaya untuk mengirim tahu ke tempat pelanggan. Rata-rata biaya yang dikeluarkan responden untuk menjual tahu sebesar Rp 784.333,00/bulan. Hanya 20\% reponden yang mengeluarkan biaya transportasi untuk membeli bahan baku.

Rata-rata biaya variabel terkecil adalah biaya pengemasan sebesar Rp 467.933,00/bulan atau 0,84\%. Biaya pengemasan dikeluarkan untuk membeli plastik putih bening dan plastik kresek putih, yang digunakan untuk membungkus tahu. Biaya pengemasan merupakan biaya variabel terkecil yang dikeluarkan responden dibandingkan biaya variabel lainnya, dikarenakan tidak semua responden menggunakan plastik untuk membungkus tahu, sebagian besar responden menjual tahu dengan menggunakan ember yang dapat digunakan berkali-kali sehingga tidak perlu mengeluarkan biaya pengemasan.

Rata-rata biaya total industri karak skala rumah tangga di Kabupaten Sukoharjo pada bulan November 2018 sebesar Rp 14.911.857. Biaya total terbesar adalah biaya eksplisit yaitu sebesar Rp 13.009.294 atau 87,24\% dari biaya total. Hal ini disebabka karena komponen biaya eksplisit lebih banyak daripada biaya implisit. Dan besarnya biaya eksplisit dipengaruhi oleh bayanya bahan yang dibutuhkan dan harga dari bahan tersebut. Besarnya biaya implisit yaitu Rp 1.902.564 atau 12,76\% dari biaya total.

Rata-rata penerimaan total industri tahu skala rumah tangga di Kecamatan Kartasura Kabupaten Sukoharjo adalah $\mathrm{Rp} 65.430 .850,00 /$ bulan. Penerimaan diperoleh dari hasil penjualan tahu (tahu putih, tahu pong, dan tahu magel) dan limbah tahu. Penerimaan terbesar diperoleh dari penjualan tahu terutama jenis tahu putih yaitu sebesar Rp 49.369.133,00/bulan atau $75,45 \%$. Hal tersebut dikarenakan hampir seluruh responden memproduksi tahu putih yaitu 96,67\% dari total responden. Rata-rata jumlah masakan tahu (tahu putih, tahu magel, tahu pong) per bulan Desember 2018 adalah 889 masakan, yang berarti dalam sebulan produsen dapat menjual 1.778 papan karena 1 masakan tahu dapat menghasilkan 2 papan tahu. Harga tahu putih pada tiap responden berbeda-beda berkisar Rp 55.000,00 sampai Rp.60.000,00 per masakan. Harga per biji tahu pong berbeda-beda tergantung ukuran tahu. Terdapat beberapa ukuran antara lain ukuran 10x15 dengan harga Rp 300,00/biji; 11x16 dengan harga $\mathrm{Rp}$ 250,00/biji; 10x15 dipencong (dipotong membelah diagonal sehingga membentuk segitiga) dengan harga Rp 150,00/biji; dan 10x13 dipencong dengan harga Rp 150,00/biji. Harga tahu magel per biji bervariasi tergantung ukurannya. Terdapat beberapa ukuran tahu magel antara lain ukuran $12 \times 30$ dengan harga $\mathrm{Rp} 150,00 /$ biji, ukuran $12 \times 17$ dengan harga Rp 250,00/biji, dan ukuran 13x17 dengan harga Rp 250,00/biji.

Penerimaan total lebih besar dari biaya total, sehingga rata-rata keuntungan yang diperoleh industri tahu skala rumah tangga di Kabupaten Sukoharjo pada bulan Desember 
ISSN : 2621-3974 (online)

Volume : 02 Number : 02 (2019)

ISSN : 2622-6154 (print)

2018 sebesar Rp 7.380.847,00. Rata-rata profitabilitas usaha industri tahu skala rumah tangga di Kecamatan Kartasura Kabupaten Sukoharjo pada bulan Desember 2018 sebesar 13\%, yang berarti bahwa setiap penerimaan sebesar Rp 100,00 maka akan menghasilkan keuntungan sebesar Rp 13,00. Semakin besar profitabilitas suatu usaha maka akan semakin besar pula keuntungan yang didapatkan oleh produsen.

Rata-rata efisiensi usaha industri tahu skala rumah tangga di Kecamatan Kartasura Kabupaten Sukoharjo sebesar 1,13. Hal ini berarti bahwa usaha industri tahu di Kecamatan Kartasura Kabupaten Sukoharjo telah efisien yang ditunjukkan dengan nilai $R / C$ ratio lebih dari satu. Nilai $R / C$ ratio 1,13 yang berarti bahwa setiap Rp 100,00 biaya yang dikeluarkan

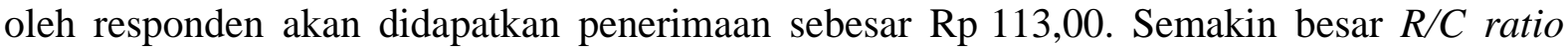
maka akan semakin besar pula penerimaan yang diperoleh responden.Saediman et al (2015) bahwa pengolahan singkong menjadi kaopi menggunakan mesin parutan dan parutan manual yang dilakukan sudah efisien karena $\mathrm{R} / \mathrm{C}$ rasio lebih dari 1 yaitu 1,5 dan 1,2.

Berdasarkan keuntungan yang diperoleh dapat dihitung simpangan baku. Simpangan baku usaha industri tahu skala rumah tangga di Kecamatan Kartasura Kabupaten Sukoharjo sebesar Rp 4.719.319,00/bulan. Besar koefisien variasi usaha industri tahu skala rumah tangga di Kecamatan Kartasura Kabupaten Sukoharjo sebesar 0,64 dengan batas bawah keuntungan negatif Rp 2.057.792,00. Hal ini menunjukkan bahwa usaha industri skala rumah tangga di Kecamatan Kartasura Kabupaten Sukoharjo berisiko karena nilai koefisien variasi lebih dari 0,5 dan berpeluang mengalami kerugian sebesar Rp 2.057.792,00/bulan. Semakin besar nilai koefisien variasi menunjukkan bahwa risiko yang harus ditanggung oleh produsen semakin besar dibanding dengan keuntungannya (Hernanto, 1993).

Menurut Horne dan Wachowicz (2005), analisis sensitivitas digunakan untuk mengetahui dampak pada suatu hasil apabila asumsi diubah dari kondisi dasarnya.

Tabel 4. Analisis Sensitivitas Usaha Industri Tahu Skala Rumah Tangga di Kecamatan Kartasura Kabupaten Sukoharjo pada Bulan Desember 2018

\begin{tabular}{|c|c|c|c|c|}
\hline \multirow[b]{2}{*}{ No } & \multirow[b]{2}{*}{ Parameter } & \multirow{2}{*}{$\begin{array}{c}\text { Rata-rata } \\
\text { Keuntungan (Rp } \\
\text { /bulan) }\end{array}$} & \multicolumn{2}{|c|}{ Penurunan Keuntungan } \\
\hline & & & $\begin{array}{c}\text { Jumlah } \\
\text { (Rp /bln) }\end{array}$ & Presentase (\%) \\
\hline 1 & Tidak mengalami perubahan parameter & 7.380 .847 & 0 & 0,00 \\
\hline 3 & Kenaikan harga bahan baku $10 \%$ & 3.630 .923 & 3.749 .924 & 50,81 \\
\hline 4 & Kenaikan harga bahan baku $15 \%$ & 1.755 .961 & 5.624 .886 & 76,21 \\
\hline 5 & Kenaikan harga bahan baku $19,68 \%$ & 996 & 7.379 .851 & 99,99 \\
\hline 6 & Kenaikan harga bahan baku $19,69 \%$ & $(2.754)$ & 7.383 .601 & 100,04 \\
\hline 7 & Kenaikan upah tenaga kerja $10 \%$ & 6.339 .152 & 1.041 .695 & 14,11 \\
\hline 8 & Kenaikan upah tenaga kerja $50 \%$ & 2.172 .372 & 5.208 .475 & 29,43 \\
\hline 9 & Kenaikan upah tenaga kerja $70 \%$ & 88.982 & 7.291 .865 & 98,79 \\
\hline 10 & Kenaikan upah tenaga kerja $70,85 \%$ & 438 & 7.380 .409 & 99,99 \\
\hline 11 & Kenaikan upah tenaga kerja $70,86 \%$ & $(604)$ & 7.381 .451 & 100,01 \\
\hline 12 & Penurunan nilai penjualan $10 \%$ & 837.762 & 6.543 .085 & 88,65 \\
\hline 13 & Penurunan nilai penjualan $11 \%$ & 183.453 & 7.197.394 & 97,51 \\
\hline 14 & Penurunan nilai penjualan $11,28 \%$ & 247 & 7.380 .600 & 100,00 \\
\hline 15 & Penurunan nilai penjualan $11,29 \%$ & $(6.296)$ & 7.387 .143 & 100,09 \\
\hline
\end{tabular}

\section{Sumber : Analisis Data Primer, 2018}

Berdasarkan hasil analisis yang telah dilakukan perubahan perubahan parameter berdampak pada keuntungan yang diperoleh responden. Perubahan harga bahan baku (kedelai) dan upah tenaga kerja maupun nilai penjualan dapat memengaruhi besarnya keuntungan. Penurunan nilai penjualan lebih sensitif atau peka dibandingkan dengan kenaikan harga bahan baku dan kenaikan upah tenaga kerja, karena penurunan nilai penjualan lebih besar pengaruhnya daripada kenaikan harga bahan baku dan kenaikan upah tenaga 


JOURNALAGRIECOBIS
ISSN : $2621-3974$ (online)
ISSN : $2622-6154$ (print)
kerja. Hal ini dapat dilihat pada keuntungan yang diperoleh pada setiap parameter,
keuntungan dari perubahan parameter yang semakin mendekati keuntungan dari keadaan
normal maka perubahan parameter tersebut kurang peka terhadap perubahan yang terjadi.
Usaha industri tahu skala rumah tangga di Kecamatan Kartasura Kabupaten Sukoharjo akan
mengalami kerugian ketika kenaikan harga bahan baku diatas 19,68\%, kenaikan upah tenaga
kerja diatas $70,85 \%$, dan penurunan nilai penjualan diatas $11,28 \%$, dikarenakan biaya yang
dikeluarkan lebih besar dari penerimaan yang diperoleh.




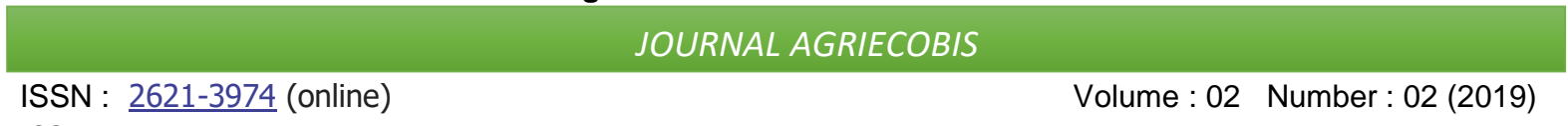

ISSN : 2622-6154 (print)

\section{KESIMPULAN}

Rata-rata biaya total usaha industri tahu skala rumah tangga di Kecamatan Kartasura Kabupaten Sukoharjo pada bulan Desember 2018 adalah Rp 58.050.003,00. Rata-rata penerimaan yang diperoleh usaha industri tahu skala rumah tangga di Kecamatan Kartasura Kabupaten Sukoharjo pada bulan Desember 2018 sebesar Rp 65.430.850,00/bulan. Sehingga rata-rata keuntungan yang diperoleh sebesar $\mathrm{Rp} 7.380 .847,00 /$ bulan dengan profitabilitas sebesar 13\%.Usaha industri tahu skala rumah tangga di Kecamatan Kartasura Kabupaten Sukoharjo yang dijalankan telah efisien karena nilai efisiensi lebih dari 1 yaitu 1,13.

Usaha industri tahu di Kecamatan Kartasura Kabupaten Sukoharjo memiliki nilai koefisien variasi (CV) lebih dari 0,5 yaitu 0,64 dan nilai batas bawah keuntungan sebesar -Rp 2.057.792,00. Hal ini berarti usaha industri tahu skala rumah tangga di Kecamatan Kartasura Kabupaten Sukoharjo berisiko dengan kemungkinan kerugian sebesar Rp 2.057.792,00/bulan.

Usaha industri tahu skala rumah tangga di Kecamatan Kartasura Kabupaten Sukoharjo menunjukkan bahwa penurunan nilai penjualan lebih sensitif atau peka jika dibandingkan dengan kenaikan harga bahan baku dan kenaikan upah tenaga kerja. Responden akan mengalami kerugian ketika penurunan nilai penjualan diatas $11,28 \%$, kenaikan bahan baku (kedelai) diatas 19,68\%, dan kenaikan upah tenaga kerja diatas 70,85\%.

\section{DAFTAR PUSTAKA}

Downey dan Erickson. 1987. Manajemen Agribisnis. Jakarta: Erlangga.

Hernanto, F. 1993. Ilmu Usahatani. Jakarta: Penebar Swadaya.

Horne dan Wachowicz. 2005. Prinsip-prinsip Manajemen Keuangan, Edisi 12. Jakarta: Salemba Empat.

Rohmah, E A dan Saputro, T B. Analisis Pertumbuhan Tanaman Kedelai (Glycine max L.) Varietas Grobogan Pada Kondisi Cekaman Genangan. Jurnal Sains dan Seni ITS 5(2): $2337-3520$.

Value Addition in Cassava Processing in Buton Districtof Southeast Sulawesi Province, Indonesia. Journal of Sustainable Development 8 (1) : 226-234.

Sarwono, B. dan Yan Pieter Saragih. 2001. Membuat Aneka Tahu. Jakarta: Penebar Swadaya.

Sudaryanto, T., \& Swastika, D. K. (2007). Ekonomi kedelai di Indonesia. Forum Agro Ekonomi (FAE), 12(3), 1-27.

Yulifianti dan Ginting, 2012. Karakteristik Tahu dari Bahan Baku Beberapa Varietas Unggul Kedelai. Prosiding Seminar Hasil Penelitian Tanaman Aneka Kacang dan Umbi 330 339. 